\title{
ADVANCED SOLAR ASSISTED DRYING SYSTEMS FOR MARINE AND AGRICULTURAL PRODUCTS
}

\author{
Kamaruzzaman Sopian*, Mohd Yusof Othman, Saleem H. Zaidi, and Nowshad Amin \\ ${ }^{1}$ Solar Energy Research Institute \\ Universiti Kebangsaan Malaysia \\ 43600 Bangi Selangor, Malaysia \\ *Corresponding email: ksopian@eng.ukm.my
}

\begin{abstract}
Solar assisted drying systems are cost effective and suitable for drying of various marine and agricultural products. The way forward for advanced solar assisted drying systems is compact collector design, high efficiency, integrated storage, and long-life systems. Air based solar collectors are not the only available systems. Water based collectors can also be used whereby water to air heat exchanger can be used. The hot air for drying of agricultural produce can be forced to flow in the water to air heat exchanger. The hot water tank acts as heat storage of the solar drying system. Heat pump drying system can be effective use for as part of solar assisted drying systems. Moreover, innovative applications of photovoltaic thermal system for simultaneous production of heat and electricity are suitable as standalone applications and totally operated on solar energy. The Solar Energy Research Institute has developed four advanced solar assisted drying system suitable for drying of various marine and agricultural products namely (a) the solar assisted drying systems with the double-pass solar collector with fins (b) solar assisted dehumidification system (c) solar assisted chemical heat pump system and (d) solar assisted heat pump with photovoltaic thermal collectors
\end{abstract}

Key Words: Double solar collector with fins, dehumidification system, chemical heat pump, photovoltaic thermal solar collector, performance, thermal efficiency.

\section{INTRODUCTION}

Direct sun drying requires large open space area, and very much dependent on the availability of sunshine, susceptible to contamination with foreign materials such as dusts, litters and are exposed to birds, insect and rodents. Hence, most agricultural and marine products that have to be stored must be dried first. Otherwise insects and fungi, which thrive in moist conditions, hence, render them unusable.

Drying is one of the oldest and most important posts handling process of agricultural products. Drying can extend shelf life, improve quality, maintain relatively constant price, reduces post harvest losses and lower transportation costs since most of the water is taken out from the product during the drying process. Most agricultural and marine products require drying process in an effort to preserve the quality of the final product. Solar assisted drying system is one of the most attractive and promising applications of solar energy systems $[1-3]$.

\section{DOUBLE PASS SOLAR COLLECTOR WITH FINS}

This drying system has capacity of of up to $300 \mathrm{~kg}$. The schematic diagram of the solar drying system and the double-pass solar collector with fins are shown in Fig. 1 and 2 [4]. The main components are solar collector array, auxiliary heater, blower, and drying chamber. The size of the chamber is $4.8 \mathrm{~m}$ in length, $1 \mathrm{~m}$ width and $0.6 \mathrm{~m}$ in height. The four collectors are set in series. The collector area is 11.52 $\mathrm{m}^{2}$, the mass flow rate is between $0.05-012 \mathrm{~kg} / \mathrm{s}$ and the average drying $50-65^{\circ} \mathrm{C}$.
The system is used to dry seaweed (eucheuma cottonii) and is a source of income, particularly in Semporna, Sabah. The seaweed industry has been carried out by communities, associations as well as individuals. Seaweed is widely used in production of food and medical products and industry manufacture at present. Problems faced by the people of seaweed farmers are raining days, requirement of large space for open drying and long drying time. Under open sun drying conditions usually it take 10-14 days for it to be $10 \%$ of original weight. The solar drying system has been evaluated for drying seaweed. The initial and final moisture content of seaweed are $90 \%$ (wet basis) and 10\% (product basis) respectively.

The drying time is about of 14 hours at average solar radiation of about $544 \mathrm{~W} / \mathrm{m} 2$ and air flow rate 0.06 $\mathrm{kg} / \mathrm{s}$. The collector, drying system and pick-up efficiencies were found to be 37, 27 and $92 \%$ respectively for $40 \mathrm{~kg}$ seaweed (Figs 3 and 4). Assuming a market value of USD6/kg, the economic analysis indicated that using the double-pass solar collector solar drying the payback period is as low as 3.14 years [5]. 

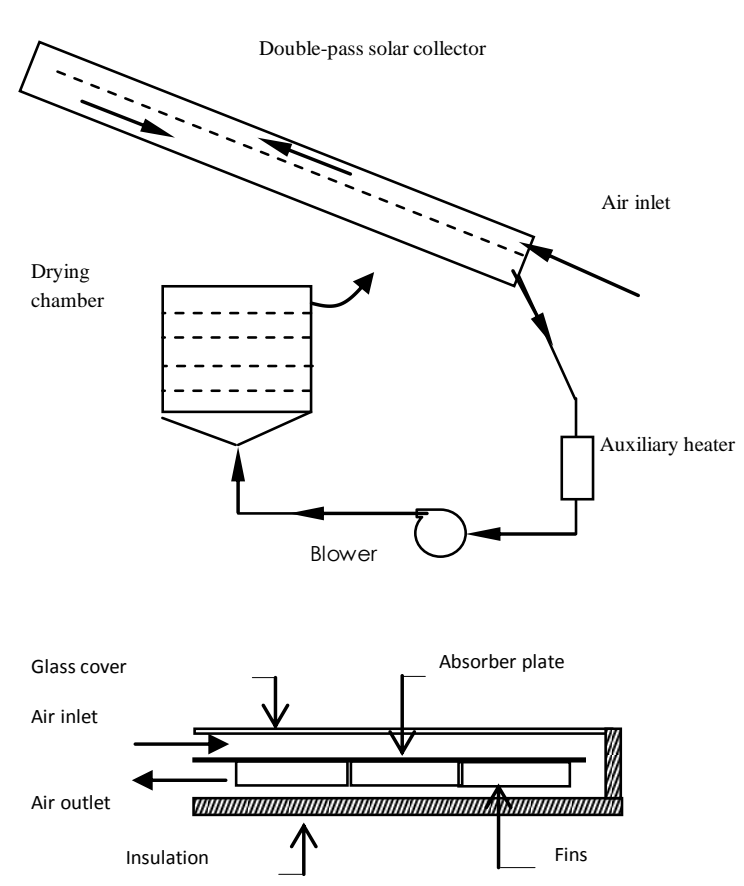

Figure 1. Schematic of the solar drying system with double-pass collector with fins.

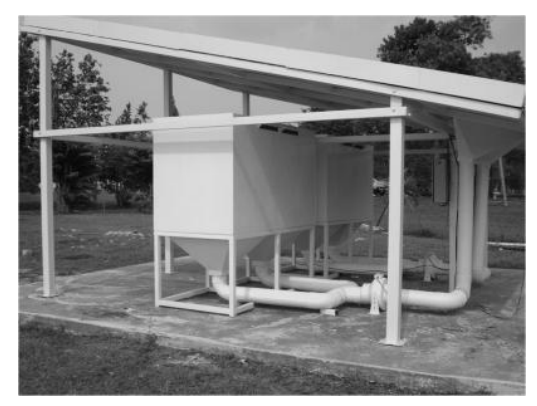

Figure 2. Photograph of the solar drying system with double-pass collector with fins.

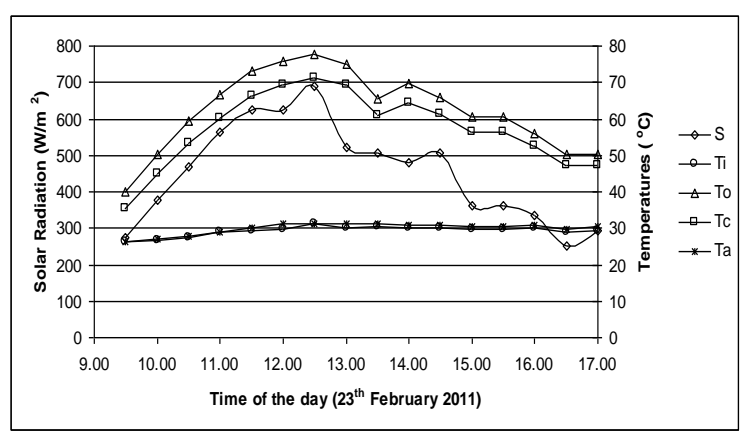

Figure 3. Solar irradiance and outlet temperatures.

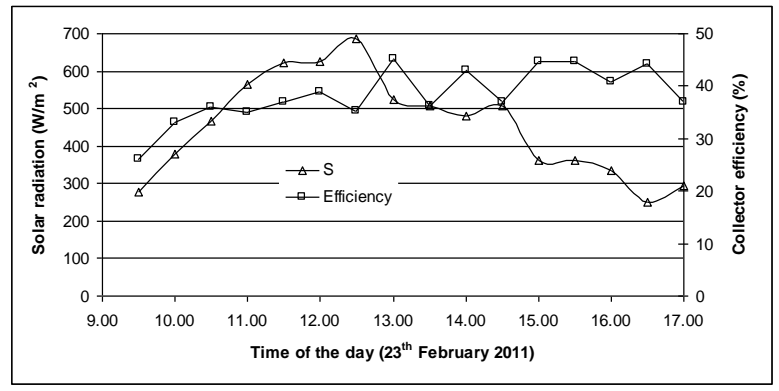

Figure 4. Solar irradiance and thermal efficiency.

\section{SOLAR ASSISTED DRYING SYSTEM WITH SOLID DESICCANT WHEEL}

Water based collectors such as evacuate tubes can be used as solar collectors for drying systems. It has the advantage of lower fluctuating temperatures and maintained a steady temperature throughout the process. However, it requires water to air heat exchangers. The system is suitable for drying of medicinal herbs. Such system is shown in Fig. 5.

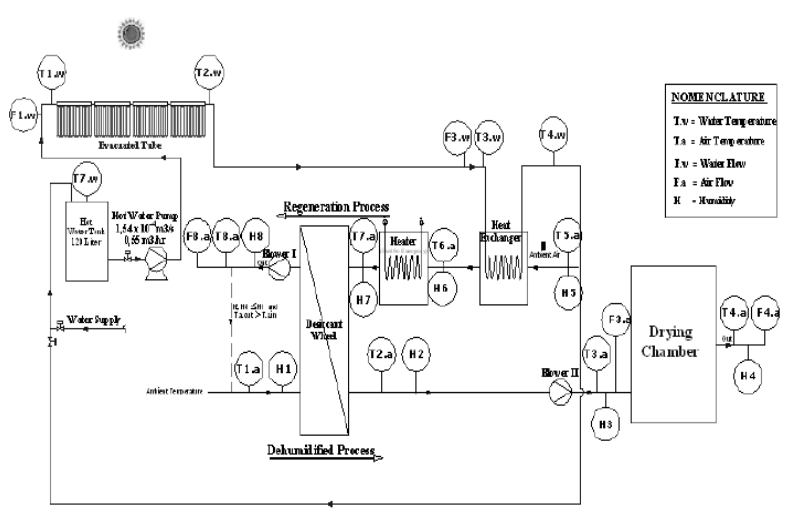

Figure 5. Solar assisted drying system with desiccant wheel.

Solar desiccant drying system has controllable and stable drying temperature and lower humidity. Many active ingredients in herbs will be destroyed if drying is carried out below $45{ }^{\circ} \mathrm{C}$ and damages will be minimal during in the drying process. This system consists of heat pipe evacuated tube collectors with area of 13:32 $\mathrm{m}^{2}$, cross flow heat exchanger for regeneration and to heat the air after dehumidification, desiccant wheel with model no. 770 WSG produced by NOVELAIRE with operating system 1:1 and maximum flow rate of $1.500 \mathrm{cfm}$. The hot water pump has a maximum capacity of 12 liters/minute and the hot water tank has maximum capacity of 230 liter. The system has a drying chamber with a capacity of $100 \mathrm{~kg}$ and electrical air heater for use when there is no sun or to increase the temperature. The use of desiccant wheel for absorbing the moisture in the dryer system is appropriate because not only the air becomes drier, 
but temperature rise is due to isotherms process. Performance of the collectors was determined. The water flow rate of 8 liters/minutes was the optimum flow in the drying process [6].

Experiments were conducted with two modes: (1) Heat exchanger to heat the air in the regeneration process and (2) Heat exchanger to heat the air after the dehumidification process, while the regeneration process utilized an electrical air heater. Effectiveness in both systems were $63.7 \%$ and $60.6 \%$ respectively. Experimental results indicated that at average solar radiation level of $505 \mathrm{~W} / \mathrm{m} 2$, mean water temperature, $\Delta \mathrm{T}$ and efficiency $76.6^{\circ} \mathrm{C}, 8.077^{\circ} \mathrm{C}$ and $68.29 \%$ respectively. At solar radiation level of $0.624 \mathrm{~kW} / \mathrm{m}^{2}$, mean water temperature, $\Delta \mathrm{T}$ and efficiency were $78.8^{\circ} \mathrm{C}, \quad 10.335^{\circ} \mathrm{C}$ and $69.56 \%$ respectively. Experiment on the desiccant wheel of mode (1) showed that the average effectiveness of sensible dehumidification, sensible regeneration, latent dehumidification and latent regeneration were $72.61 \%, 82.13 \%, 79.32 \%$ and $78.91 \%$ respectively. In mode (2), the average effectiveness of sensible dehumidification, sensible regeneration, latent dehumidification and latent regeneration were $71.4 \%$, $71.99 \%, 66.97 \%$ and $72.8 \%$ respectively. Mode (1) was better than mode (2) with mean drying air temperature and absolute humidity were $58^{\circ} \mathrm{C}$ and $0.0157 \mathrm{~kg}\left(\mathrm{H}_{2} \mathrm{O}\right) / \mathrm{kg}$ (dry air) respectively. The system was able to evaporate $10.5 \mathrm{~kg}\left(\mathrm{H}_{2} \mathrm{O}\right) / \mathrm{hr}$ of water in the materials at pick up efficiency of 55\%. Caption of the data acquisition system are shown in Fig. 6 [7].

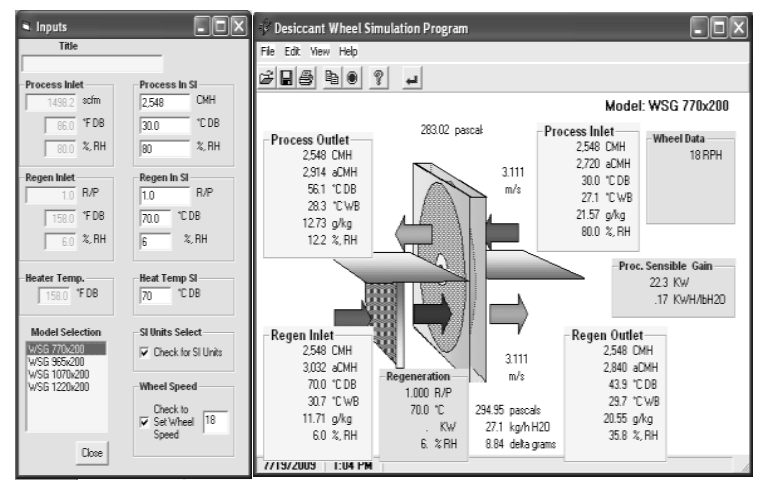

Figure 6. Data acquisition system for solar drying system with solid desiccant wheel.

\section{SOLAR ASSISTED CHEMICAL HEAT PUMP DRYING SYSTEM}

he principal advantages of heat pump dryers are energy from the ability of the heat pumps to recover energy from the exhaust gas as well as their ability to control the drying gas temperature and humidity. Heat application can be classified into air source heat-pump drying systems, ground source heat-pump drying systems, and chemical heat-pump drying systems. Chemical heat pump (CHP) is potentially significant technologies for effective energy utilization in drying. CHPs are those systems that utilize the reversible chemical reaction to change the temperature level of the thermal energy which stored by chemical substance.

These chemical substances play an important role in absorbing and releasing heat. The advantages of thermochemical energy storage, such as high storage capacity, long term storage of both reactants and products lower of heat loss, suggests that CHP could be an option for energy upgrading of low temperature heat as well as storage. A solar-assisted chemical heat-pump dryer has been designed and built, as shown in Figs. 7 and 8 [8].The system consists of four mean components solar collector (evacuated tubes type), storage tank, chemical heat pump unit and dryer chamber. In this study, a cylindrical tank is selected as a storage tank. The chemical heat pump unit consists of reactor, evaporator and condenser. In the chemical heat pump a solid gas reactor is coupled with a condenser or an evaporator. The reaction is:

$$
\mathrm{CaC}_{12} \cdot 2 \mathrm{NH}_{3}+6 \mathrm{NH}_{3} \rightarrow \mathrm{CaC}_{12} \cdot 8 \mathrm{NH}_{3}+6 \Delta \mathrm{Hr}
$$

The drying chamber contains multiple trays to hold the drying material and expose it to the air flow. The chemical heat pump operates in heat pump mode. The overall operation of chemical heat pump occurs in two stages: adsorption and desorption. The adsorption stage is the cold production stage, and this is followed by the regeneration stage, where decomposition takes place. During the production phase, the liquid-gas transformation of ammonia produces cold at low temperature in the evaporator. At the same time, chemical reaction between the gaseous ammonia and solid would release heat of reaction at higher temperature.

The incoming air is heated by condensing refrigerant (ammonia) and enters the dryer inlet at the drying condition and performs drying. After the drying process, part of the moist air stream leaving the drying chamber is diverted through the evaporator, where it is cooled, and dehumidification takes place as heat is given up to the refrigerant (ammonia). The air is then passing through the condenser where it is reheated by the condensing refrigerant and then to the drying chamber.

The product used for drying was lemongrass. Lemongrass is commonly used in teas, soups, and curries. It is also suitable for poultry, fish, beef, and seafood. The temperature $55^{\circ} \mathrm{C}$ and two air drying speed $(1 \mathrm{~m} / \mathrm{s}$, and $3 \mathrm{~m} / \mathrm{s})$ has been investigated. The weight was recorded on personal computer at 5 minutes intervals, and about $65 \mathrm{~g}$ of fresh lemongrass was used in each run. The lemongrass was dried from average initial moisture content of $85 \%$ wb to an average final moisture content of $13 \%$ wb. Fig 9 shows the COP of the system for a suns day. 


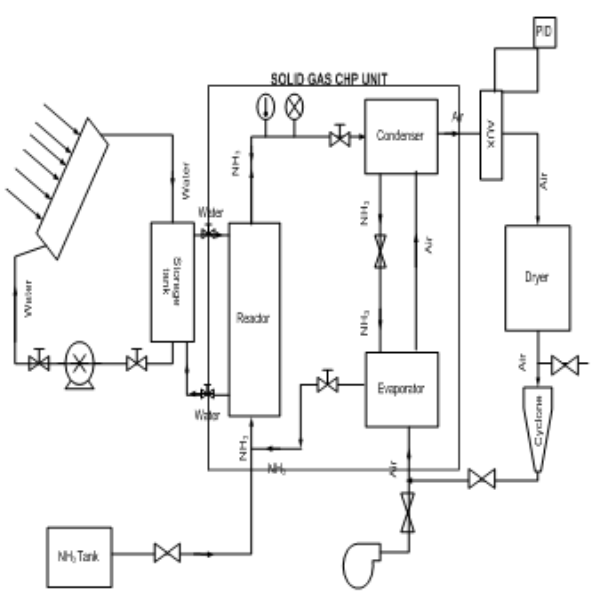

Figure7. Schematic diagram of solar assisted chemical heat pump dryer.

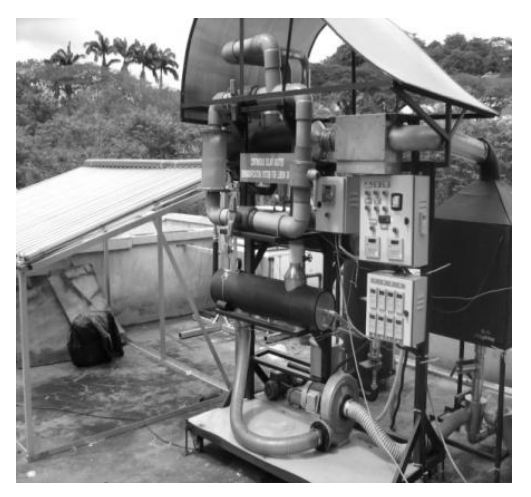

Figure 8. Photograph of the experimental set-up.

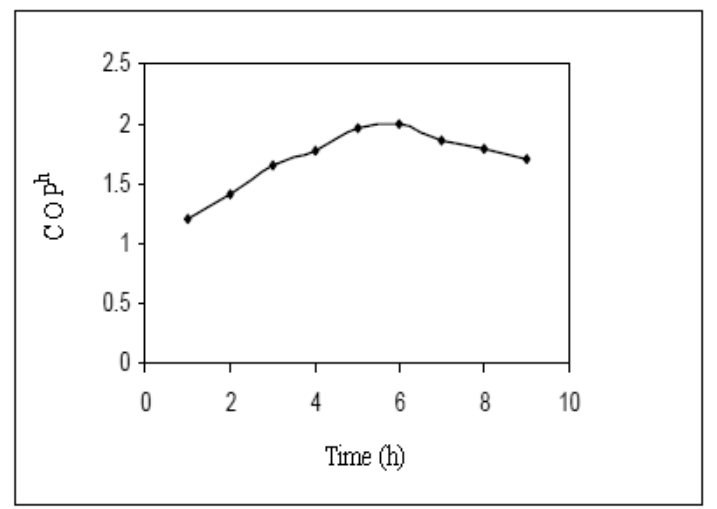

Figure 9. Coefficient of performance experimental curve against time for sunny day.

The maximum value of solar fraction of 0.713 and the maximum value of coefficient of permance of chemical heat pump $\left(\mathrm{COP}_{\mathrm{h}}\right)$ of 2 were obtained from experiment at sunny day. The total system energy output from the experiment at sunny day was $51 \mathrm{kwh}$. The results show that any reduction of energy at condenser as a result of a decrease in solar radiation will decrease the coefficient of performance as well as decrease the efficiency of drying.

\section{SOLAR ASSISTED HEAT PUMP WITH PHOTOVOLTAIC THERMAL COLLECTOR}

Normally, solar thermal collectors and photovoltaic panels are used separately. These two systems can be combined together in a hybrid photovoltaic thermal (PVT) energy system. The term PVT refers to solar thermal collectors that use PV cells as an integral part of the absorber plate. The system generates both thermal and electrical energy simultaneously. The number of the photovoltaic cells in the system can be adjusted according to the local load demands.

In conventional solar thermal system, external electrical energy is required to circulate the working fluid through the system. The need for an external electrical source can be eliminated by using this hybrid system. With a suitable design, one can produce a self-sufficient solar collector system that required no external electrical energy to run the system [9]. Photovoltaic (PV) modules convert a part of solar radiation energy directly into electricity, while, the unconverted part of the solar radiation into electricity is absorbed in a PV module resulting in very high temperatures.

A combined solar assisted heat pump water heating, air conditioning and drying system using water and refrigerant based PV/T collectors has been designed, fabricated and tested as shown in Figs. 10 and 11. The direct integration of PV panels, thermal absorbers and heat pump system consists of a compressor, one air cooled condenser, a water cooled condenser, one evaporator as dehumidifier, one evaporator as air conditioner, expansion valves which are interconnected in a closed-loop system, a drying chamber, one auxiliary heater, storage tank, water pump and one water-refrigerant heat exchanger. This system was consists of three distinct flow paths: water, refrigerant and air. The performance of the system has been investigated theoretically and experimentally under the meteorological conditions of Malaysia.

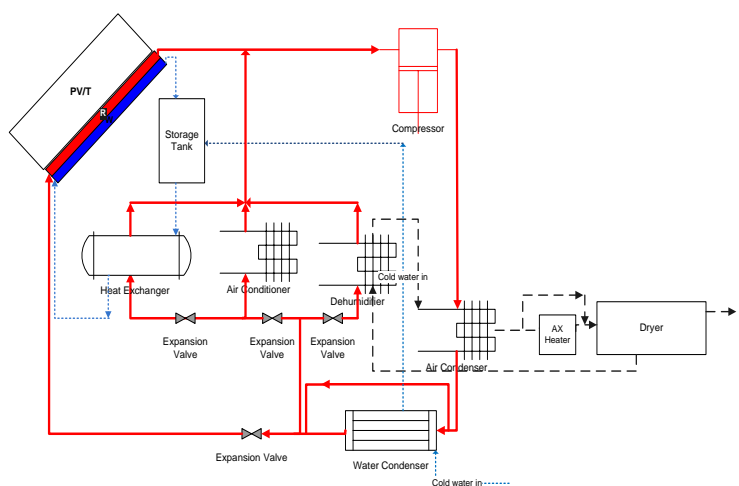

Figure 10. Schematics of the PVT System. 


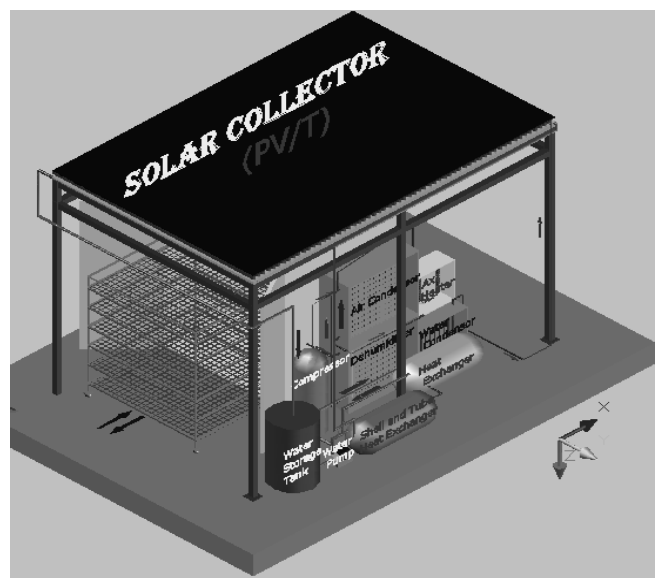

Figure 11. PV/T heat pump dryer and water heater system layouts.

In order to test short term performance, high and low irradiance days in August and March were chosen, individually and water heating, drying and air conditioner modes have been tested within these days. Furthermore, the PV/T module performance was studied experimentally and theoretically. The findings of the experimental study were in good agreement with the theoretical predictions on the system for each individual mode. Guava, a tropical fruits was dried using the dryer [10-11].

The experimental values of water temperature in water heating mode show that the water temperatures increased up to $71^{\circ} \mathrm{C}$ and $62.6^{\circ} \mathrm{C}$ for high irradiance days in August and March, respectively. The highest average indoor temperature range during the high radiance days in air conditioner mode was measured between 27-28.8 ${ }^{\circ} \mathrm{C}$ and the lowest indoor temperature between $22.8-24{ }^{\circ} \mathrm{C}$, while the highest average indoor temperature range for low irradiance days was shown as 24.6-27.1 ${ }^{\circ} \mathrm{C}$ and also lowest indoor temperature as $22.8-23.7{ }^{\circ} \mathrm{C}$. The $\mathrm{COP}$ for all the modes is shown in Figs 12 through 14.

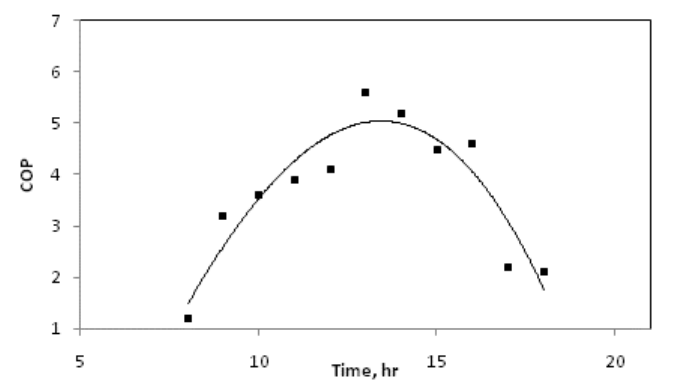

Figure 12. COP of Water Heating Mode.

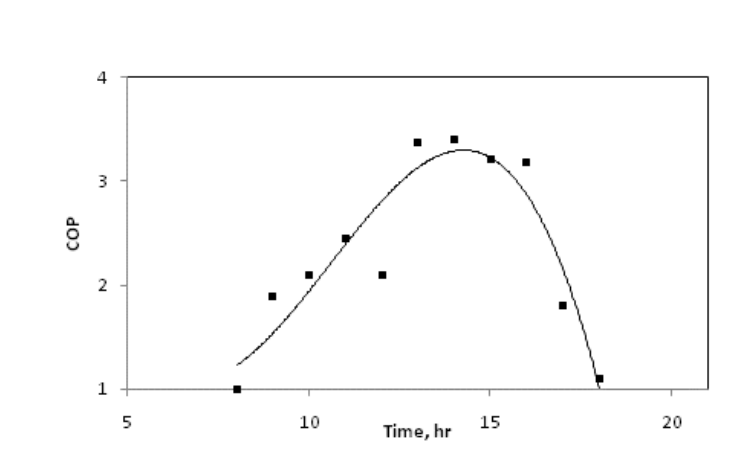

Figure 13. COP of Air Conditioner Mode.

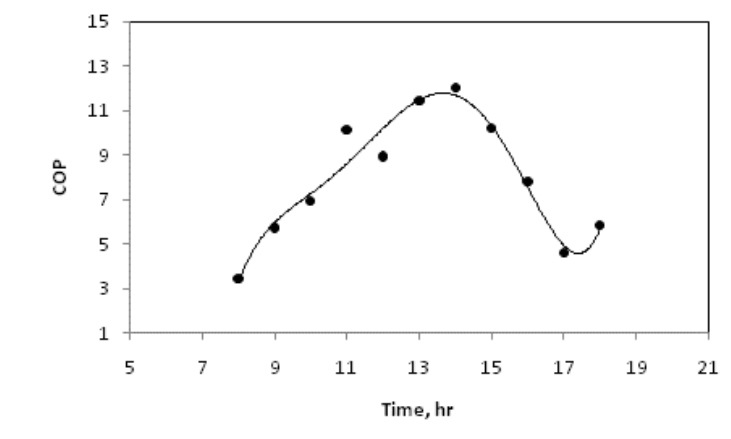

Figure 14. COP of Dryer Mode.

The electrical and thermal efficiencies ranges for $\mathrm{PV} / \mathrm{T}$ evaporator-collector were found above the range of $7.71 \%-7.9 \%$ and $76 \%-79 \%$, accordingly while water collector obtained electrical and thermal efficiencies $5 \%-5.4 \%$ and $58 \%-68 \%$, for high irradiation days. The results indicated that the performance of two cooling medium PV/T collectors is higher than the performance in the other types of $\mathrm{PV} / \mathrm{T}$ systems. The overall performance of the system is determined by the coefficient of performance of system and solar fraction for each mode. A maximum coefficient of performance of 5.6-6.9, 4.1-4.43 and 12-14.1 obtained from experimental work for water heating, space cooling and drying mode for high irradiation days, respectively. Moreover, the highest values of solar fraction which obtained from the experimental work for water and refrigerant and water based parts are between 0.67 and 0.77 for water heating mode, 0.62 and 0.76 for space cooling and 0.69 and 0.78 for drying mode in high irradiance days, separately. The techno-economical evaluation for the system was conducted using TRNSYS software. A 20-year life-cycle economic analysis generally showed that hybrid system has a payback period of 2.3 years and the average annual savings was USD 3382.

\section{CONCLUSION}

The potential of using solar energy in the agricultural and marine sectors have increased due to fluctuation in the price of fossil fuel, environmental concerns and expected depletion of conventional fossil fuels. Solar 
assisted drying system is one of the most attractive and promising applications of solar energy systems. Direct sun drying are subjected to many issues including availability of drying areas and exposure to birds, insect and rodents which has consequences with regards the quality of the products.

Other limitations were given by the availability of appropriate drying equipment which is technically and economically feasible and the lack of knowledge how to process agricultural products. Up to now only a few solar dryers who meet the technical, economical and socio-economical requirements are commercially available. Most solar dryers are simple, low power, short life, and comparatively low efficiency-drying system. The solar assisted drying systems presented in this paper are high efficiency, high power, long life and expensive drying systems. However, deciding factor for any solar driers should be based on economics. Economic decisions are about choices among possible alternatives of action in the future. The approach is to minimize input (cost) for a give output (benefits), or to maximize the output (benefits) from a given input (cost). The simple solar will have lower output compared to the more sophisticated solar drying systems. Hence, the payback period for such higher efficiency and productivity solar dryers should be much lower that the simple solar dryers. In addition, the solar dryers presented in this paper have very stable output temperature and higher performance. Materials for construction for these solar are also available locally.

\section{REFERENCES}

[1] M.Y.H. Othman, K. Sopian , B. Yatim , W.R.W. Daud, Development of advanced solar assisted drying systems, Renewable Energy 31 (2006) 703709.

[2] M.I. Fadhel, K. Sopian, W.R.W. Daud, M.A. Alghoul, Review on advanced of solar assisted chemical heat pump dryer for agriculture produce, Renewable and Sustainable Energy Reviews, Volume 15, Issue 2, February 2011, Pages 11521168

[3] A. Fudholi, K. Sopian, M.H. Ruslan, M.A. Alghoul, M.Y. Sulaiman, Review of solar dryers for agricultural and marine products, Renewable and Sustainable Energy Reviews, Volume 14, Issue 1, January 2010, Pages 1 - 30

[4] Ronak Daghigh, Mohd Hafidz Ruslan, Mohamad Yusof Sulaiman, Kamaruzzaman Sopian, Review of solar assisted heat pump drying systems for agricultural and marine products, Renewable and Sustainable Energy Reviews, Volume 14, Issue 9, December 2010, Pages 2564-2579

[5] A. Fudholi, M. Y. Othman, M. H. Ruslan, M. Yahya, A. Zaharim and K.Sopian. 2011. Design and Testing of Solar Dryer for Drying Kinetics of Seaweed in Malaysia. Recent Researches in Geography, Geology, Energy, Environment and
[6] A. Fudholi, M. Y. Othman, M. H. Ruslan, M. Yahya, A. Zaharim and K. Sopian. 2011. The Effects of Drying Air Temperature and Humidity on the Drying Kinetics of Seaweed. Recent Researches in Geography, Geology, Energy, Environment and Biomedicine. Corfu Island, Greece, July 14-16. Pg: 129-133. ISBN: 978-1-61804-022-0

[7] Tri Suyono, Sohif Mat, Muhammad Yahya, Muhd. Hafiz Ruslan, Azami Zaharim, Kamaruzzaman Sopian, Theoretical and Experimental Analysis of Desiccant Wheel Performance for Low Humidity Drying System, Proceedings of the 10th WSEAS International Conference on System Science and Simulation in Engineering (ICOSSSE '11), Penang, Malaysia, October 3-5, 2011, ISBN: 978-1-61804-041-1pp 132137.

[8] M.I. Fadhel, K. Sopian, W.R.W. Daud, M.A. Alghoul, Performance analysis of solar-assisted chemical heat-pump dryer Solar Energy, Volume 84, Issue 11, November 2010, Pages 1920-1928

[9] Sopian, K. 2008. Advances in Photovoltaic Thermal (PVT) Solar Collectors. In: Proceedings of the 2nd WSEAS/IASME International Conference on ENERGY PLANNING, ENERGY SAVING, ENVIRONMENTAL EDUCATION (EPESE'08), at Corfu, Greece, October 26-28: Plenary Lecture IV.

[10] R. Daghigh, M.H. Ruslan, A. Zaharim. K.Sopian. Monthly Performance of a Photovoltaic Thermal (PV/T) Water Heating System. Proceedings of the 6th IASME / WSEAS International Conference on ENERGY \& ENVIRONMENT(EE'11). Cambridge,UK ,February,23-25,2011.

[11] K.Sopian. Effect of Packing Factor on the Performance of PV/T Water Heater. Proceedings of the 6th IASME / WSEAS International Conference on ENERGY \&ENVIRONMENT(EE'11). Cambridge,UK ,February,23-25,2011

\section{NOMENCLATURE}

\begin{tabular}{c|l|l}
\hline Symbol & Meaning & Unit \\
\hline A & area & $\left(\mathrm{m}^{2}\right)$ \\
COP & $\begin{array}{l}\text { coefficient of performance } \\
\text { driving ratio(pressure ratio } \\
\text { br }\end{array}$ & \\
& $\begin{array}{l}\text { between the generator and the } \\
\text { evaporator) }\end{array}$ & \\
$\mathrm{L}$ & length & $(\mathrm{mm})$ \\
$\mathrm{P}$ & Pressure & $(\mathrm{Pa})$ \\
$\mathrm{T}$ & Temperature & $(\mathrm{K})$ \\
$\square$ & Tilt angle of solar collector & \\
$\phi$ & Latitude angle & \\
$w$ & Entrainment ration & \\
\hline
\end{tabular}

